\title{
Faktor-Faktor Yang Mempengaruhi Nilai Perusahaan Pada Perusahaan Property Dan Real Estate Di Bursa Efek Indonesia
}

\author{
Amin Wijoyo \\ Universitas Tarumanagara \\ aminw@fe.untar.ac.id
}

\begin{abstract}
The purpose of this study is to test and to analyze the association of asset structure, profitability, debt policy, dividend policy either partially or simultaneously, to compnay value of property and real estate firm that listed at Indonesian Stock Exchange in the period of 2014-2016. The method used is multiple regression analysis using SPSS 23. The result show that asset structure, profitability, debt policy, dividend policy have a simultaneous influence with company value. Meanwhile, partially only profitability have a influence with company value. Asset structure, debt policy, and dividend policy not have a influence with company value.
\end{abstract}

Keywords: Struktur Aset, Profitabilitas, Debt to Equity Ratio, Kebijakan Deviden, Nilai Perusahaan

\begin{abstract}
Abstrak: Tujuan penelitian ini adalah untuk mengetahui dan menganalisis seberapa besar pengaruh variabel independen Struktur Aset, Profitabilitas, Kebijakan hutang, dan Kebijakan Deviden baik secara parsial ataupun secara simultan berpengaruh terhadap Nilai Perusahaan. Populasi pada penelitian ini adalah pada perusahaan property dan real estate yang terdaftar di Bursa Efek Indonesia untuk periode 2014 sampai 2016. Sampel pada penelitian ini dipilih dengan menggunakan metode purposive sampling sehingga digunakan sebanyak 22 perusahaan dari 47 perusahaan yang akan dijadikan sebagai objek penelitian. Adapun hasil penelitian yang diperoleh yaitu: struktur aset, profitabilitas, kebijakan hutang, dan kebijakan deviden secara bersama-sama mempunyai pengaruh yang signifikan terhadap nilai perusahaan. Secara parsial profitabilitas mempunyai pengaruh yang signifikan terhadap nilai perusahaan sedangkan struktur aset, kebijakan hutang, dan kebijakan deviden tidak mempunyai pengaruh yang signifikan terhadap nilai perusahaan.
\end{abstract}

Kata kunci: Struktur Aset, Profitabilitas, Debt to Equity Ratio, Kebijakan Deviden, Nilai Perusahaan

\section{PENDAHULUAN}

Semua perusahaan yang ada di dunia sudah pasti menginginkan laba dalam menjalankan kegiatan operasionalnya untuk melanjutkan kegiatan operasional perusahaan. Selain itu perusahaan terutama yang memiliki saham di perusahaan menginginkan keuntungan yang tinggi untuk mendapatkan deviden yang besar. Semakin besar deviden yang dibagikan oleh perusahaan tentu akan menjadi nilai tambah bagi perusahaan dan mendorong investor untuk melakukan investasi di perusahaan. Nilai perusahaan pada dasarnya dapat diukur melalui beberapa aspek, salah satunya adalah dengan harga pasar saham perusahaan karena harga pasar perusahaan mencerminkan penilaian investor terhadap perusahaan secara keseluruhan. Harga pasar saham meningkat maka akan meningkatkan kekayaan para pemegang saham. 
Brigham dan Houston (2010;132) menyatakan bahwa memaksimalkan kekayaan pemegang saham dalam jangka panjang adalah tujuan utama manajemen keuangan. Optimalisasi nilai perusahaan ini dapat dicapai melalui pelaksanaan fungsi manajemen keuangan yang dimana satu keputusan keuangan yang diambil akan berdampak pada keputusan keuangan yang lainnya yang pada akhirnya akan mempengaruhi nilai perusahaan. Bagi manajemen, nilai suatu perusahaan dapat memberikan petunjuk mengenai apa yang dipikirkan oleh investor atas kinerja perusahaan di masa lalu serta prospek perusahaan di masa yang akan datang.

Menurut Weston dan Brigham (1993), struktur modal yang optimal merupakan salah satu cara untuk meningkatkan harga pasar saham. Perusahaan dengan struktur modal yang tidak baik dan hutang yang sangat besar akan memberikan beban berat kepada perusahaan sehingga perlu diusahakan suatu keseimbangan yang optimal dalam menggunakan kedua sumber tersebut sehingga dapat memaksimalkan nilai perusahaan. Debt to Equity Ratio (DER) juga menunjukkan tingkat hutang perusahaan, perusahaan dengan hutang yang besar mempunyai biaya hutang yang besar pula. Semakin likuid perusahaan, maka semakin tinggi tingkat kepercayaan kreditur dalam memberikan dananya, sehingga dapat meningkatkan nilai perusahaan di mata kreditur maupun pada calon investor.

Dalam konsep signaling theory, bahwa pembayaran deviden akan menjadi suatu sinyal positif dari manajemen yang digunakan untuk memberikan gambaran tentang masa depan suatu perusahaan berdasarkan tingkat profitabilitas yang terbentuk, dan secara langsung yang akan meningkatkan nilai dari perusahaan yang diindikasikan dengan semakin meningkatnya harga saham di pasar. Sektor manufaktur memiliki masa depan yang kuat di Indonesia, karena perkembanganya dan memberikan kontribusi terbesar terhadap Produk Domestik Bruto (PDB) Indonesia. Kebijakan deviden yang diambil oleh perusahaan adalah merupakan kebijakan apakah akan membayar atau tidak, serta menentukan besarnya deviden yang akan dibayarkan sama atau lebih besar dari tahun sebelumnya.

Berikut hasil penelitian yang dilakukan Meiriska Febrianti dengan judul faktor-faktor yang mempengaruhi nilai perusahaan pada industri pertambangan di bursa efek indonesia memperoleh hasil secara parsial Struktur Aset mempunyai pengaruh yang tidak signifikan terhadap nilai perusahaan, Profitabilitas mempunyai pengaruh yang positif terhadap nilai perusahaan walaupun tidak signifikan, likuiditas mempunyai pengaruh yang positif terhadap terhadap nilai perusahaan namun tidak signikan, pertumbuhan perusahaan mempunyai pengaruh yang positif dan signifikan terhadap nilai perusahaan, ukuran perusahaan menunjukkan pengaruh yang positif dan signifikan terhadap nilai perusahaan, DER (Debt to Equity Ratio) mempunyai pengaruh yang signifikan terhadap nilai perusahaan, leverage mempunyai pengaruh yang signifikan terhadap nilai perusahaan namun tidak signifikan.

Kemudian hasil penelitian yang dilakukan oleh Robinhot Gultom, Agustina, dan Sri Widia Wijaya dengan judul Analisis faktor yang mempengaruhi nilai perusahaan pada perusahaan farmasi di bursa efek indonesia memperoleh hasil secara parsial struktur modal berpengaruh signifikan terhadap nilai perusahaan, berarti variabel struktur modal memiliki pengaruh terhadap nilai perusahaan namun tidak signifikan di tahun berikutnya, likuiditas berpengaruh negatif dan tidak signifikan, menunjukkan adanya pengaruh antara variabel likuiditas terhadap nilai perusahaan namun tidak signifikan ditahun berikutnya, ukuran perusahaan berpengaruh negatif dan tidak signifikan terhadap nilai perusahaan, ukuran suatu perusahaan mempengaruhi nilai perusahaan namun tidak signifikan ditahun 
berikutnya, profitabilitas memiliki pengaruh positif dan signifikan terhadap nilai perusahaan, keuntungan suatu perusahaan memiliki pengaruh yang sejalan terhadap nilai perusahaan.

Penilitan berikutnya dilakukan oleh Endang Mahpudin dengan judul Faktor-faktor yang mempengaruhi nilai perusahaan (Studi empiris pada perusahaan manufaktur yang terdaftar di Bursa Efek Indonesia) yang memperoleh hasil secara simultan Kebijakan deviden dan profitabilitas mempunyai pengaruh yang signifikan terhadap nilai perusahaan sedangkan secara parsial Kebjiakan deviden berpengaruh terhadap nilai perusahaan, Profitabilitas berpengaruh terhadap nilai perusahaan.

Tujuan dari penelitian ini adalah Untuk menguji pengaruh struktur aset, kondisi keuangan perusahaan, kebijakan hutang, dan kebijakan deviden baik secara parsial ataupun secara simultan berpengaruh terhadap nilai perusahaan pada perusahaan property dan real estate yang terdaftar di Bursa Efek Indonesia pada tahun 2014 sampai dengan tahun 2016.

\section{KAJIAN TEORI}

Nilai Perusahaan. Menurut Sartono (2010:487), nilai Perusahaan adalah nilai jual sebuah perusahaan sebagai suatu bisnis yang sedang beroperasi. Adanya kelebihan nilai jual diatas nilai likuidasi adalah nilai dari organisasi manajemen yang menjalankan perusahaan itu sedangkan menurut Harmono (2009:233), nilai Perusahaan adalah kinerja perusahaan yang dicerminkan oleh harga saham yang dibentuk oleh permintaan dan penawaran pasar modal yang merefleksikan penilaian masyarakat terhadap kinerja perusahaan. Nilai perusahaan (company value) merupakah sebuah nilai yang dapat digunakan untuk mengukur seberapa besar "Tingkat Kepentingan" sebuah perusahaan dilihat dari sudut pandang beberapa pihak seperti para investor yang mengaitkan nilai sebuah perusahaan dari harga sahamnya. Dalam jangka panjang tujuan perusahaan adalah memaksimumkan nilai perusahaan. Semakin tinggi nilai perusahaan menggambarkan semakin sejahtera pula pemiliknya.

Struktur Aset. Struktur Aset menurut Weston dan Brigham (2005:175) struktur aktiva adalah: perimbangan atau perbandingan antara aktiva tetap dan total aktiva. Perusahaan dengan struktur aset yang fleksibel cenderung menggunakan leverage yang lebih besar daripada perusahaan yang struktur asetnya tidak fleksibel. Berdasarkan cara dan lamanya perputaran, kekayaan suatu perusahaan dapat dibedakan antara aset lancer dan aset tidak lancar. Perbandingan atau pertimbangan antara kedua aset tersebut akan menentukan struktur aset. Komposisi antara aset lancar dengan aset tidak lancar dalam perusahaan akan menentukan pilihan sumber pendanaan yang tepat. Perusahaan yang mempunyai jenis aktiva yang sesuai untuk jaminan kredit akan cenderung menggunakan hutang karena kemudahan yang dimiliki. Oleh karena itu perusahaan daapt memperoleh sumber dana lebih mudah, sehingga dapat meningkatkan nilai perusahaan.

Profitabilitas. Rasio profitabilitas merupakan rasio yang bertujuan untuk mengetahui kemampuan perusahaan dalam menghasilkan laba selama periode tertentu dan juga memberikan gambaran tentang tingkat efektifitas manajemen dalam melaksanakan kegiatan operasinya. Efektifitas manajemen disini dilihat dari laba yang dihasilkan terhadap penjualan dan investasi perusahaan. Rasio ini disebut juga rasio rentabilitas. 
Rasio profitabilitas merupakan rasio yang menggambarkan kemampuan perusahaan dalam mendapatkan laba melalui semua kemampuan dan sumber yang ada seperti kegiatan penjualan, kas, modal, jumlah karyawan, jumlah cabang dan sebagainya (Syafri, 2008:304). Menurut Pecking Order Theory, penggunaan hutang dalam struktur modalnya. Hal ini disebabkan karena perusahaan dengan profitabilitas yang tinggi akan mempunyai dana internal yang besar, dan akan menggunakan dana internalnya terlebih dahulu sebelum mengambil pembiayaan eksternal melalui hutang. Profitabilitas merupakan tingkat keuntungan bersih yang dapat diperoleh sebuah perusahaan dari kegiatan operasionalnya yang mana keuntungan tersebut ada yang dibagikan kepada pemegang saham dalam bentuk deviden, dan bisa juga keuntungan tersebut disimpan dan digunakan untuk meningkatkan kinerja kegiatan operasional.

Kebijakan hutang atau Debt to Equity Ratio. Menurut Sri Hermuningsih dan Dewi Kusuma Wardani (2009:175), menyatakan bahwa kebijakan hutang merupakan: "Keputusan penggunaan hutang dengan mempertimbangkan biaya tetap yang muncul dari hutang berupa bunga, yang akan menyebabkan semakin meningkatnya leverage keuangan dan semakin tidak pastinya tingkat pengembalian bagi para pemegang saham biasa". Struktur modal merupakan perimbangan jumlah hutang jangka pendek yang bersifat permanen, hutang jangka panjang, saham preferen, dan saham biasa. Struktur modal yang optimal adalah perbandingan antara nilai hutang dengan ekuitas yang memaksimalkan harga saham perusahaan. Menurut Jensen (1976) nilai perusahaan dapat meningkat dengan adanya hutang tersebut digunakan bukan untuk investasi yang tidak menguntungkan, melainkan digunakan untuk mengendalikan penggunaan arus kas secara berlebihan oleh pihak manajemen. Peningkatan nilai tersebut dikaitkan dengan harga saham dan penurunan hutang akan menurunkan harga saham. Di satu sisi hutang bisa membuat pertumbuhan sebuah perusahaan menjadi lebih cepat jika dibandingkan dengan modal sendiri. Debt to Equity Ratio (DER) memberikan gambaan mengenai sruktur modal yang dimiliki oleh perusahaan dan juga menunjukkan tingkat hutang perusahaan.

Kebijakan deviden menurut Martono dan D. Agus Harjito (2000:253) merupakan bagian yang tidak dapat dipisahkan dengan keputusan pendanaan perusahaan. Kebijakan dividen (dividend policy) merupakan keputusan apakah laba yang diperoleh perusahaan pada akhir tahun akan dibagi kepada pemegang saham dalam bentuk dividen atau akan ditahan untuk menambah modal guna pembiayaan investasi di masa yang akan datang. Selain itu menurut Menurut Adler Haymans Manurung (2012) "Kebijakan dividen menyangkut tentang masalah penggunaan laba yang menjadi hak pemegang saham. Pada dasarnya, laba tersebut bisa dibagi sebagai dividen atau ditahan untuk diinvestasikan kembali". Kebijakan deviden (dividend policy) adalah masalah penting, karena tidak hanya jumlah uang yang terlibat dan sifat berulang dari dividend payout. Kebijakan pembayaran deviden memiliki hubungan erat dengan sebagian besar investasi perusahaan dan kebijakan keuangan lainnya. Kebijakan dalam pembayaran deviden merupakan hal yang rumit pada suatu perusahaan, karena melibatkan dua pihak yang memiliki kepentingan berbeda yaitu antara pemegang saham dan pihak manajemen perusahaan sendiri. Kebijakan deviden merupakan penentuan keputusan atas laba yang diperoleh perusahaan, antara jumlah yang akan dibagikan kepada para pemegang saham atau disebut juga sebagai deviden dan laba yang akan diinvestasikan kembali pada perusahaan atau disebut juga laba ditahan. 


\section{Skema Kerangka Pemikiran}

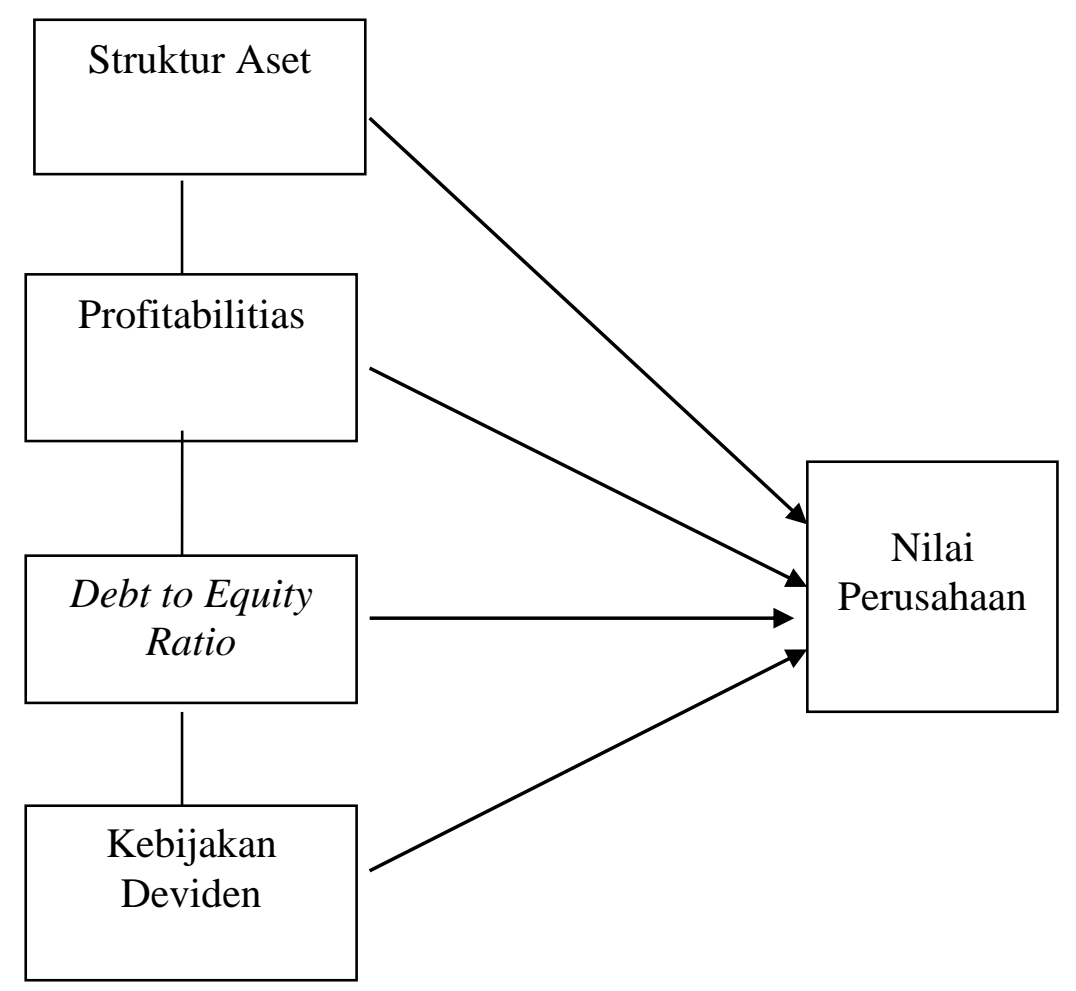

Berdasarkan uraian di atas maka dapat disusun delapan hipotesis, yakni adalah sebagai berikut:

$\mathrm{Ha}_{1}$ : Struktur aset, profitabilitas, ukuran perusahaan, debt equity ratio, kebijakan deviden memiliki pengaruh yang signifikan terhadap nilai perusahaan

$\mathrm{Ha}_{2}$ : Struktur aset memiliki pengaruh yang signifikan terhadap nilai perusahaan.

$\mathrm{Ha}_{3}$ : Profitabilitas memiliki pengaruh yang signifikan terhadap nilai perusahaan.

Ha4: Debt equity ratio memiliki pengaruh yang signifikan terhadap nilai perusahaan.

Ha5: Kebijakan deviden memiliki pengaruh yang signifikan terhadap nilai perusahaan

\section{METODE}

Populasi dan Teknik Pemilihan Sampel. Populasi penelitian adalah perusahaan yang bergerak dalam industri property dan real estate yang terdaftar di Bursa Efek Indonesia (go public). Penarikan sampel dilakukan dengan metode purposive atau judgement sampling di mana sampel yang diambil dari populasi harus memenuhi kriteria tertentu, yaitu merupakan perusahaan yang bergerak dalam industri property dan real estate yang telah terdaftar di Bursa Efek Indonesia sampai dengan akhir tahun 2016, perusahaan mempunyai catatan mengenai laporan keuangan disajikan dalam mata uang Rupiah, mempunyai data keuangan (laporan tahunan) yang lengkap, dan memperoleh laba dari tahun 2014-2016. Data yang digunakan dalam penelitian ini adalah data sekunder. Data sekunder yang digunakan adalah laporan keuangan perusahaan tahun 2014-2016 yang telah diaudit. Laporan keuangan yang digunakan diperoleh melalui situs www.idx.co.id.

Operasionalisasi Variabel. Nilai Perusahaan. Nilai suatu perusahaan yang dapat diukur dari harga saham perusahaan saat ini. 


$$
\text { PER }=\frac{\text { Harga saham saat ini }}{\text { laba bersih per saham }}
$$

Sumber : Robinhot, Agustina, dan Sri Widia. 2013.

Struktur Aset. Struktur aktiva adalah komposisi pembelanjaan perusahaan yang mencerminkan perbandingan antara aktiva lancar dan aktiva tetap. Perbandingan ini akan menentukan struktur kekayaan perusahaan.

$$
\text { Struktur Aset }=\quad \frac{\text { Fixed Asset }}{\text { Total Asset }}
$$

Sumber : Meiriska Febrianti. 2012.

Profitabilitas. Rasio profitabilitas merupakan rasio yang bertujuan untuk mengetahui kemampuan perusahaan dalam menghasilkan laba selama periode tertentu dan juga memberikan gambaran tentang tingkat efektifitas manajemen dalam melaksanakan kegiatan operasinya

$$
\text { Profitability }=\frac{\text { Operating Profit }}{\text { Net Revenues }}
$$

Sumber : Meiriska Febrianti. 2012.

Debt to Equity Ratio. kemampuan perusahaan untuk melunasi hutangnya dengan modal yang dimiliki.

$$
\text { DER }=\frac{\text { Total Debt }}{\text { Total Equity }}
$$

Sumber : Robinhot, Agustina, dan Sri Widia. 2013.

Kebijakan Deviden. Kebijakan deviden menyangkut tentang masalah penggunaan laba yang menjadi hak pemegang saham

$1=$ Ada pembagian deviden

$0=$ Tidak Ada pembagian Deviden

Persamaan regresi berganda yang diintepretasikan dalam penelitian ini adalah:

$$
Y=a+b_{1} X_{1}+b_{2} X_{2}+b_{3} X_{3}+b_{4} X_{4}+b_{5} X_{5}+e
$$

Keterangan: $\mathrm{Y}=$ Nilai Perusahaan; $\mathrm{a}=$ Nilai intercept atau konstanta; $\mathrm{b}_{1}, \mathrm{~b}_{2}, \mathrm{~b}_{3}, \mathrm{~b}_{4}, \mathrm{~b}_{5}=$ Koefisien regresi, yaitu besarnya perubahan $\mathrm{Y}$ apabila $\mathrm{X}$ berubah sebesar satu satuan; $\mathrm{X}_{1}$ $=$ Struktur Aset; $\mathrm{X}_{2}=$ Profitabilitas; $\mathrm{X}_{3}=$ Ukuran Perusahaan; $\mathrm{X}_{4}=$ Debt to Equity Ratio $; \mathrm{X}_{5}=$ Kebijakan Deviden; e $=$ Error

\section{HASIL DAN PEMBAHASAN}

Sebelum melakukan analisis dan pembahasan lebih lanjut, terlebih dahulu dilakukan statistik deskriptif untuk menggambarkan karakteristik data yang digunakan dalam penelitian ini. Hasil statistik deskriptif yang dihasilkan melalui program Statistical Product and Services Solutions 23 (SPSS 23) dapat dilihat pada tabel di bawah yang disajikan secara keseluruhan (2014-2016). 
Tabel. Statistik Deskriptif Keseluruhan Tahun 2014-2016

\begin{tabular}{|c|c|c|c|c|c|}
\hline \multicolumn{6}{|c|}{ Descriptive Statistics } \\
\hline & $\mathrm{N}$ & Minimum & Maximum & Mean & Std. Deviation \\
\hline $\begin{array}{l}\text { Nilai_Perusah } \\
\text { aan }\end{array}$ & 66 & .421386833898 & 1.801003000833 & 1.10740723250905 & .271162053584639 \\
\hline Struktur_Aset & 66 & -2.19802935740 & -.10213326067 & -1.1648362425828 & .50148872042988 \\
\hline Profitabilitas & 66 & -.983236611396 & .049634377192 & -.53706287831253 & .212600123233561 \\
\hline DER & 66 & -.830546915214 & .263350591914 & -.14809839745725 & .276413752657469 \\
\hline $\begin{array}{l}\text { Kebijakan_D } \\
\text { eviden }\end{array}$ & 66 & 0 & 1 & .74 & .441 \\
\hline $\begin{array}{l}\text { Valid N } \\
\text { (listwise) }\end{array}$ & 66 & & & & \\
\hline
\end{tabular}

Sumber: Hasil Pengolahan SPSS 23

Tabel di atas menggambarkan karakteristik dari variabel-variabel yang diteliti pada tahun 2014-2016. Pada kolom N, dapat diketahui bahwa data yang diproses berjumlah 66, yang merupakan sampel rata-rata dari tahun 2014 sampai tahun 2016. Variabel Struktur Aset pada tahun 2014-2016 mempunyai nilai minimum sebesar -2.19802935740 dan nilai maksimum sebesar -.10213326067, hal ini menunjukkan bahwa Struktur aset pada tahun 2014-2016 berkisar antara -2.19802935740 sampai -.10213326067. Range Struktur aset pada tahun 2014-2016 berdasarkan nilai minimum dan maksimum adalah 2.095896096730. Rata-rata Struktur aset pada tahun 2014-2016 adalah -1.1648362425828 dengan Standar deviasi Struktur Aset pada tahun 2014-2016 adalah 0.50148872042988. Jadi struktur aset perusahaan property dan real estate yang terdaftar di BEI pada sampel tidak terdapat perbedaan aset yang cukup signifikan.

Variabel Profitabilitas tahun 2014-2016 memiliki nilai minimum dan nilai maksimum sebesar -0.983236611396 dan 0.049634377192 , sehingga range Profitabilitas tahun 2014-2016 adalah 1.032870988588. Rata-rata profitabilitas tahun 2014-2016 sebesar -0.53706287831253 dan memiliki standar deviasi sebesar 0.212600123233561 . Hal ini menunjukkan bahwa Profitabilitas dari sampel perusahaan property dan real estate di BEI 2014-2016 tidak mempunyai perbedaan yang cukup signifikan berarti keuntungan perusahaan dengan nilai saham perusahaan.

Variabel Debt to Equity Ratio tahun 2014-2016 memiliki nilai minimum sebesar 0.830546915214 dan nilai maksimum sebesar 0.263350591914 , dengan range sebesar 1.093897507128. Rata-rata Debt to Equity Ratio tahun 2014-2016 sebesar 0.14809839745725 , sedangkan standar deviasinya adalah sebesar 0.276413752657469 . Jadi Debt to Equity Ratio pada perusahaan property dan real estate yang terdaftar di BEI pada sampel tidak terdapat perbedaan kebijakan hutang yang cukup signifikan.

Variabel Nilai perusahaan tahun 2014-2016 mempunyai nilai minimum sebesar 0.421386833898 dan nilai maksimum sebesar 1.801003000833 , dengan range sebesar 1.379616166935.. Rata-rata nilai perusahaan tahun 2014-2016 sebesar 1.10740723250905 dengan Standar deviasi nilai perusahaan tahun 2014-2016 sebesar 0.271162053584639. Jadi nilai perusahaan pada perusahaan property dan real estate yang terdaftar di BEI pada sampel tidak terdapat perbedaan nilai perusahaan yang cukup signifikan.

Sebelum pengujian hipotesis dilakukan, terlebih dahulu dilakukan uji asumsi klasik. Uji asumsi klasik yang dilakukan dalam penelitian terdiri dari uji normalitas, uji heteroskedastisitas, uji multikolinieritas, dan uji autokorelasi. Pengujian asumsi klasik 
dilakukan untuk tahun 2014 sampai dengan tahun 2016, baik secara gabungan maupun secara masing-masing.

Uji Normalitas. Pengujian normalitas pada penelitian ini dilakukan dengan menggunakan One-Sample Kolmogorov-Smirnov Test. Jika signifikansi residu lebih besar dari 0,05, maka model regresi memenuhi asumsi normalitas. Hasil pengujian normalitas untuk tahun 2014-2016 dapat dilihat pada tabel sebagai berikut:

Tabel 2. One-Sample Kolmogorov-Smirnov Test

\begin{tabular}{llr}
\hline & & $\begin{array}{c}\text { Unstandardized } \\
\text { Residual }\end{array}$ \\
\hline $\mathrm{N}$ & & 66 \\
Normal Parameters & Mean & .0000000 \\
& Std. Deviation & .24341125 \\
Most Extreme & Absolute & .092 \\
Differences & Positive & .092 \\
& Negative & -.037 \\
Test Statistic & & .092 \\
Asymp. Sig. (2-tailed) & $.200^{\mathrm{c}, \mathrm{d}}$ \\
\hline \multicolumn{2}{l}{ a. Test distribution is Normal. } \\
b. Calculated from data. \\
c. Lilliefors Significance Correction. \\
d. This is a lower bound of the true significance. \\
Sumber: Hasil Pengolahan SPSS 23
\end{tabular}

Model regresi tahun 2014-2016 telah memenuhi asumsi normalitas karena unstandardized residual memiliki asymp. sig. di atas 0,05, yaitu sebesar 0,200. Dengan demikian, model regresi tahun 2014-2016 layak digunakan.

Uji Heteroskedastisitas. Pengujian heteroskedastisitas dalam penelitian ini dilakukan dengan menggunakan uji Spearman's Rho. Jika signifikansi unstandardized residual dengan variabel return on asset, debt equity ratio, current ratio, atau dengan ukuran perusahaan lebih besar dari 0,05, maka dapat disimpulkan bahwa pada model regresi tidak terjadi heteroskedastisitas. Hasil pengujian heterokedastisitas untuk tahun 2014-2016 adalah sebagai berikut:

Tabel 3. Correlations

\begin{tabular}{|c|c|c|c|c|c|c|c|}
\hline & & & $\begin{array}{c}\text { Struktur } \\
\text { Asset }\end{array}$ & Profitabilitas & DER & $\begin{array}{c}\text { Kebijakan_D } \\
\text { eviden }\end{array}$ & $\begin{array}{c}\text { Unstanda } \\
\text { rdized } \\
\text { Residual }\end{array}$ \\
\hline \multirow[t]{3}{*}{$\begin{array}{l}\text { Spearma } \\
\text { n's rho }\end{array}$} & $\begin{array}{l}\text { Struktur_ } \\
\text { Aset }\end{array}$ & $\begin{array}{l}\text { Correlation } \\
\text { Coefficient }\end{array}$ & 1.000 & -.055 & -.099 & .183 & -.015 \\
\hline & & Sig. (2-tailed) & . & .660 & .427 & .142 & .907 \\
\hline & & $\mathrm{N}$ & 66 & 66 & 66 & 66 & 66 \\
\hline
\end{tabular}




\begin{tabular}{|c|c|c|c|c|c|c|}
\hline $\begin{array}{l}\text { Profitabil } \\
\text { itas }\end{array}$ & $\begin{array}{l}\text { Correlation } \\
\text { Coefficient }\end{array}$ & -.055 & 1.000 & $.399^{-}$ & -.088 & .057 \\
\hline & Sig. (2-tailed) & .660 & . & .001 & .481 & .651 \\
\hline & $\mathrm{N}$ & 66 & 66 & 66 & 66 & 66 \\
\hline DER & $\begin{array}{l}\text { Correlation } \\
\text { Coefficient }\end{array}$ & -.099 & $-.399^{* *}$ & 1.000 & .226 & -.015 \\
\hline & Sig. (2-tailed) & .427 & .001 & . & .068 & .906 \\
\hline & $\mathrm{N}$ & 66 & 66 & 66 & 66 & 66 \\
\hline $\begin{array}{l}\text { Kebijaka } \\
\text { n_Devide }\end{array}$ & $\begin{array}{l}\text { Correlation } \\
\text { Coefficient }\end{array}$ & .183 & -.088 & .226 & 1.000 & -.023 \\
\hline $\mathrm{n}$ & Sig. (2-tailed) & .142 & .481 & .068 & . & .856 \\
\hline & $\mathrm{N}$ & 66 & 66 & 66 & 66 & 66 \\
\hline $\begin{array}{l}\text { Unstanda } \\
\text { rdized }\end{array}$ & $\begin{array}{l}\text { Correlation } \\
\text { Coefficient }\end{array}$ & -.015 & .057 & -.015 & -.023 & 1.000 \\
\hline Residual & Sig. (2-tailed) & .907 & .651 & .906 & .856 & \\
\hline & $\mathrm{N}$ & 66 & 66 & 66 & 66 & 66 \\
\hline
\end{tabular}

Sumber: Hasil Pengolahan SPSS 23

Berdasarkan Tabel di atas dapat dilihat bahwa korelasi antara unstandardized residual dengan stuktur aset memiliki signifikansi sebesar 0,907, dengan profitabilitas memiliki signifikansi sebesar 0,651, dengan DER memiliki signifikansi sebesar 0,906, dan dengan kebijakan deviden memiliki signifikansi sebesar 0,856. Dengan demikian, dapat disimpulkan bahwa model regresi tahun 2014-2016 bebas dari masalah heteroskedastisitas.

Uji Multikolinieritas. Pengujian multikolinearitas dalam penelitian ini dilakukan dengan melihat nilai tolerance dan variance inflation factor pada kolom Collinearity Statistics pada tabel Coefficients. Suatu model regresi dikatakan tidak terjadi kolinearitas ganda jika mempunyai nilai tolerance di atas 0,10 dan nilai variance inflation factor kurang dari 10 . Hasil pengujian multikolinearitas tahun 2014-2016 adalah sebagai berikut:

Tabel 4.Uji Multikolinieritas Tahun 2014-2016

\begin{tabular}{|c|c|c|c|c|c|c|c|c|}
\hline \multicolumn{9}{|c|}{ Coefficients $^{\mathbf{a}}$} \\
\hline & & \multicolumn{2}{|c|}{$\begin{array}{c}\text { Unstandardized } \\
\text { Coefficients }\end{array}$} & \multirow{2}{*}{$\begin{array}{c}\text { Standardized } \\
\text { Coefficients } \\
\text { Beta } \\
\end{array}$} & \multirow[b]{2}{*}{$\mathrm{t}$} & \multirow[b]{2}{*}{ Sig. } & \multicolumn{2}{|c|}{$\begin{array}{c}\text { Collinearity } \\
\text { Statistics }\end{array}$} \\
\hline \multicolumn{2}{|c|}{ Model } & $\mathrm{B}$ & Std. Error & & & & Tolerance & VIF \\
\hline \multirow[t]{4}{*}{1} & (Constant) & .890 & .155 & & 5.755 & .000 & & \\
\hline & Struktur_Aset & -.002 & .065 & -.004 & -.034 & .973 & .912 & 1.097 \\
\hline & Profitabilitas & -.331 & .165 & -.260 & -2.006 & .049 & .788 & 1.270 \\
\hline & DER & .193 & .133 & .197 & 1.453 & .151 & .717 & 1.396 \\
\hline
\end{tabular}




\begin{tabular}{llllllll}
\hline $\begin{array}{l}\text { Kebijakan_Dev } \\
\text { iden }\end{array}$ & .088 & .074 & .143 & 1.186 & .240 & .903 & 1.107 \\
\hline
\end{tabular}

a. Dependent Variable: Nilai_Perusahaan

Sumber : Hasil Pengolahan SPSS 23

Nilai tolerance pada variabel Struktur aset, profitabilitas, DER, dan kebijakan deviden adalah $0,912,0,788,0,717$, dan 0,903 . Selain itu, nilai variance inflation factor pada variabel Struktur aset, profitabilitas, DER, dan kebijakan deviden adalah 1.097, 1.270, 1,396, dan 1,107. Dengan demikian, dapat disimpulkan bahwa pada model regresi tahun 2014-2016 tidak terjadi masalah multikolinieritas.

Uji Autokorelasi. Pengujian autokorelasi dalam penelitian ini menggunakan uji run test dimana suatu model regresi dikatakan tidak mengalami masalah autokorelasi jika nilai Asymp. Sig. (2-tailed) $>0,05$.

Tabel 5. Runs Test

\begin{tabular}{lr}
\hline & Unstandardized Residual \\
\hline Test Value $^{\mathrm{a}}$ & -.01576 \\
Cases $<$ Test Value & 33 \\
Cases $>=$ Test Value & 33 \\
Total Cases & 66 \\
Number of Runs & 28 \\
$Z$ & -1.489 \\
Asymp. Sig. (2-tailed) & .137 \\
\hline
\end{tabular}

a. Median

Sumber: Hasil Pengolahan SPSS 23

Model regresi tahun 2014-2016 tidak memiliki masalah autokorelasi. Hal ini dikarenakan nilai Asymp.Sig. (2-tailed) yang dapat dilihat pada tabel di atas, yaitu sebesar 0.137. Setelah dilakukan pengujian regresi berganda secara gabungan untuk tahun 2014-2016, maka didapatkan hasil yang akan ditampilkan pada tabel berikut ini:

Tabel 6. Hasil Pengujian Regresi Berganda Tahun 2014-2016

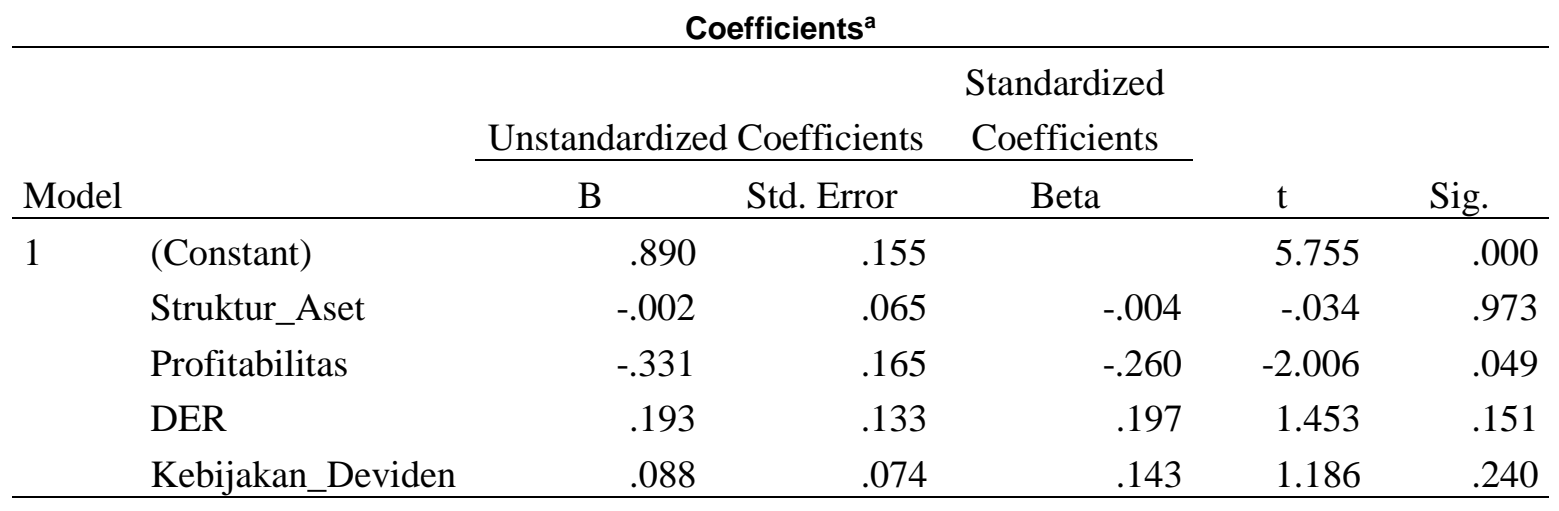

a. Dependent Variable: Nilai_Perusahaan

Sumber: Hasil Pengolahan SPSS 23 
Dari hasil pengujian regresi berganda di atas, dapat dirumuskan persamaan regresi berganda untuk tahun 2014-2016 sebagai berikut:

$$
\mathrm{Y}=0.890-0.002 \mathrm{X}_{1}-0.331 \mathrm{X}_{2}+0.193 \mathrm{X}_{3}+0.088 \mathrm{X}_{4}
$$

Keterangan: $\mathrm{X}_{1}=$ Struktur Aset; $\mathrm{X}_{2}=$ Profitabilitas; $\mathrm{X}_{3}=$ Kebijakan Hutang; $\mathrm{X}_{4}=$ Kebijakan Deviden

Nilai konstanta pada persamaan regresi di atas adalah .890 . Hal ini berarti jika struktur aset, profitabilitas, kebijakan hutang, dan kebiajkan deviden sama dengan nol dan jika ditambah dengan R Squarenya sebesar 0.194 maka nilai perusahaan adalah 1.084.

Koefisien regresi struktur aset adalah 0.002, yang berarti jika struktur aset bertambah 1 satuan, maka nilai perusahaan akan turun 0.002 satuan, dengan asumsi variabel independen lainnya adalah konstan. Struktur aset berpengaruh tidak signifikan terhadap nilai perusahaan dimana pengaruh tersebut secara negatif maka semakin besar struktur aset perusahaan maka semakin kecil nilai perusahaanya. Hasil ini sesuai dengan penelitian yang dilakukan Merisika Febrianti yang juga hasilnya struktur aset tidak mempengaruhi nilai perusahaan.

Koefisien regresi profitabilitas adalah 0.331, yang berarti jika profitabilitas bertambah 1 satuan, maka nilai perusahaan akan turun 0.331 satuan, dengan asumsi variabel independen lainnya adalah konstan. profitabilitas berpengaruh tidak signifikan terhadap nilai perusahaan dimana pengaruh tersebut secara negatif maka semakin besar profitabilitas perusahaan maka semakin kecil nilai perusahaanya. Hasil ini sesuai dengan penelitian yang dilakukan Merisika Febrianti yang juga hasilnya struktur aset tidak mempengaruhi nilai perusahaan tetapi tidak sama dengan penelitian yang dilakukan oleh Robinhot Gultom, Agustina, Sri Widia Wijaya dan penelitian oleh Endang Mahpudin yang hasilnya profitabilitas mempunyai pengaruh yang signifikan dan positif terhadap nilai perusahaan.

Koefisien regresi kebijakan hutang adalah 0.193, yang berarti jika kebijakan hutang bertambah 1 satuan, maka nilai perusahaan akan bertambah 0.193 satuan, dengan asumsi variabel independen lainnya adalah konstan. Kebijakan hutang tidak berpengaruh signifikan terhadap nilai perusahaan dimana pengaruh tersebut secara positif semakin besar kebijakan hutang maka semakin besar nilai perusahaanya. Hasil ini tidak sama dengan penelitian yang dilakukan Merisika Febrianti yang juga hasilnya kebijakan hutang signifikan mempengaruhi nilai perusahaan.

Koefisien regresi kebijakan deviden adalah 0.088, yang berarti jika kebijakan hutang bertambah 1 satuan, maka nilai perusahaan akan bertambah 0.088 satuan, dengan asumsi variabel independen lainnya adalah konstan. Kebijakan deviden tidak berpengaruh signifikan terhadap nilai perusahaan dimana pengaruh tersebut secara positif semakin besar kebijakan deviden maka semakin besar nilai perusahaanya. Hasil ini tidak sesuai dengan penelitian yang dilakukan Endang Mahpudin yang hasilnya kebijakan deviden berpengaruh signifikan terhadap nilai perusahaan.

Hasil pengujian hubungan variabel independen secara simultan dengan variabel dependen untuk tahun 2014-2016 ditampilkan pada tabel di bawah. Jika nilai signifikansi $\mathrm{F}$ lebih kecil dari $\alpha=0,05$, maka $\mathrm{Ho}_{1}$ akan ditolak. 
Tabel 7. ANOVA ${ }^{\mathrm{a}}$

\begin{tabular}{llrrrrr}
\hline Model & & Sum of Squares & df & Mean Square & F & \multicolumn{1}{c}{ Sig. } \\
\hline 1 & Regression & 1.131 & 5 & .226 & 3.719 & $.005^{\mathrm{b}}$ \\
& Residual & 3.649 & 60 & .061 & & \\
& Total & 4.779 & 65 & & & \\
\hline
\end{tabular}

a. Dependent Variable: Nilai_Perusahaan

b. Predictors: (Constant), Kebijakan_Deviden, Profitabiitas, Struktur_Aset,

Ukuran_Perusahaan, DER

Sumber: Hasil Pengolahan SPSS 23

Pada anova dapat diketahui nilai signifikansi $\mathrm{F}$ adalah sebesar 0,005. Hal ini menunjukkan bahwa $\mathrm{Ho}_{1}$ ditolak, karena nilai signifikansi $\mathrm{F}$ lebih kecil daripada nilai $\alpha$ yang sebesar 0,05. Dengan demikian, secara gabungan tahun 2014-2016, struktur aset, profitabilitas, kebijakan hutang(DER), dan kebijakan deviden mempunyai hubungan secara simultan yang signifikan dengan nilai perusahaan. Dalam menentukan apakah variabel-variabel dependen mempengaruhi variabel indenpenden maka perlu dilihat dari uji regresi yaitu melihat huruf R.

Tabel 8. Model Summary ${ }^{\mathrm{b}}$

\begin{tabular}{llrrr}
\hline Model & R & R Square & Adjusted R Square & Std. Error of the Estimate \\
\hline 1 & $.441^{\mathrm{a}}$ & .194 & .141 & .251265236473181 \\
\hline
\end{tabular}

a. Predictors: (Constant), Kebijakan_Deviden, Profitabilitas, Struktur_Aset, DER

b. Dependent Variable: Nilai_Perusahaan

Sumber: Hasil Pengolahan SPSS 23

Angka $R$ Square tahun 2014-2016 yang sebesar .194, dapat dilihat pada tabel di atas, menunjukkan bahwa 14,1 \% dari variasi variabel nilai perusahaan dapat dijelaskan oleh variabel struktur aset, profitabilitas, debt to equity ratio, dan kebijakan deviden. Sedangkan, sisanya sebesar 85,9 \% dapat dijelaskan oleh variabel lain, seperti tingkat pertumbuhan penjualan.

Nilai perusahaan masi dipengaruhi oleh faktor-faktor lain seperti:

1. Peluang Pertumbuhan dengan Nilai Perusahaan. Pertumbuhan perusahaan merupakan variabel yang dipertimbangkan dalam keputusan hutang. Brigham dan Gapenski (1997) menyatakan bahwa perusahaan yang memiliki tingkat pertumbuhan yang tinggi cenderung membutuhkan dana dari sumber eksternal yang besar. Tingkat pertumbuhan perusahaan juga merupakan faktor yang mempengaruhi struktur modal, perusahaan yang memiliki tingkat pertumbuhan pesat cenderung lebih banyak menggunakan hutang daripada perusahaan yang memiliki tingkat pertumbuhan yang lebih lambat (Weston dan Brigham 1993)

2. Tingkat suku bunga dengan nilai perusahaan. Suku bunga merupakan biaya modal bagi perusahaan, dimana suku bunga yang tinggi berarti biaya penggunaan dana semakin tinggi sehingga perusahaan enggan untuk melakukan peminjaman dan akibatnya leverage akan menurun. Keadaan pasar modal yang semakin bergairah akan mengurangi minat perusahaan untuk melakukan peminjaman karena perusahaan lebih tertarik melakukan pembiayaan melalui pasar modal sehingga leverage menurun. 
3. Likuiditas dengan nilai perusahaan. Likuiditas adalah kemampuan perusahaan dalam memenuhi kewajiban jangka pendeknya. Likuiditas juga dapat diartikan sebagai kemampuan seseorang atau perusahaan untuk memenuhi kewajiban atau hutang yang segera harus dibayar dengna harta lancarnya. Likuiditas menunjukkan kemampuan suatu perusahaan untuk memenuhi kewajiban keuangannya yang harus segera dipenuhi, atau kemampuan perusahaan untuk memenuhi kewajiban keuangan pada saat ditagih.

4. Ukuran perusahaan dengan nilai perusahaan. Besar atau kecil perusahaan menjadi salah satu variabel yang dianggap dapat mempengaruhi keputusan perusahaan dalam memilih bentuk pendaaan. Ukuran perusahaan akan berpengaruh pada kebijakan hutang perusahaan. Perusahaan yang besar dan mempunyai reputasi yang baik di pasar akan lebih banyak menggunakan hutang sebagai sumber pendanaan. Peningkatan hutang tersebut dapat meningkatkan nilai perusahaan. Ukuran perusahaan dapat digunakan sebagai proksi untuk probabilitas perusahaan mengalami defisit dengan asumsi bahwa biaya kebangkutan tetap serta merupakan fungsi yang menurun terhadap nilai perusahaan. Perusahaan besar biasanya melakukan diversifikasi usah, sehingga kemungkinan kebangkrutan menjadi lebih rendah. Selain itu diversifikasikan juga dapat mengoptimalkan penggunaan target rasio hutang yang meningkat. Ukuran perusahaan yang besar bisa merefleksikan pencapaian tingkat profit yang lebih baik di masa mendatang.

\section{PENUTUP}

Penelitian ini dilakukan dengan tujuan untuk menganalisa hubungan struktur aset, profitabilitas, debt to equity ratio, dan kebijakan deviden dengan nilai perusahaan pada perusahaan property dan real estate yang terdaftar di Bursa Efek Indonesia pada tahun 2014 sampai tahun 2016. Model regresi berganda dalam penelitian ini telah memenuhi semua uji asumsi klasik, yang terdiri dari uji normalitas, uji homoskedastisitas, uji multikolinieritas, dan uji autokorelasi. Berdasarkan hasil analisa, dapat ditarik beberapa kesimpulan. Kesimpulan diambil berdasarkan hasil penelitian secara parsial maupun keseluruhan, baik dari segi variabel independen maupun dari segi tahun penelitian.

Hasil penelitian menunjukkan bahw: (1) Struktur aset berpengaruh tidak signifikan terhadap nilai perusahaan dimana pengaruh tersebut secara negatif maka semakin besar struktur aset perusahaan maka semakin kecil nilai perusahaanya; (2) Profitabilitas berpengaruh tidak signifikan terhadap nilai perusahaan dimana pengaruh tersebut secara negatif maka semakin besar profitabilitas perusahaan maka semakin kecil nilai perusahaanya; (3) Kebijakan hutang tidak berpengaruh signifikan terhadap nilai perusahaan dimana pengaruh tersebut secara positif semakin besar kebijakan hutang maka semakin besar nilai perusahaanya;(4) Kebijakan deviden tidak berpengaruh signifikan terhadap nilai perusahaan dimana pengaruh tersebut secara positif semakin besar kebijakan deviden maka semakin besar nilai perusahaanya; (5) Struktur aset, profitabilitas, kebijakan hutang(DER), dan kebijakan deviden mempunyai hubungan secara simultan yang signifikan dengan nilai perusahaan.

Hasil penelitian menunjukkan bahwa secara parsial, variabel yang memiliki hubungan yang signifikan dengan nilai perusahaan tahun 2014-2016 adalah profitabilitas sedangkan variabel yang tidak memiliki hubungan secara signifikan dengan nilai perusahaan adalah struktur aset, kebijakan hutang, dan kebijakan deviden. 
Saran. Berdasarkan hasil penelitian, dapat diberikan saran bagi manajemen perusahaan, bagi kreditor, dan bagi penelitian selanjutnya. (1) Bagi kreditor adalah perlunya mempertimbangkan faktor-faktor yang mempengaruhi dengan nilai perusahaan sebelum mengambil keputusan terkait dengan membeli saham di perusahaan. Perlu dievaluasi faktor-faktor tersebut sebelum melakukan investasi di perusahaan. (2) Bagi manajemen perusahaan adalah meningkatkan kinerjanya sehingga faktor-faktor yang dipertimbangkan oleh investor akan menunjukkan hasil yang baik. Dengan demikian, dapat menarik pihak investor untuk membeli saham di perusahaan tersebut. (3) Bagi peneliti selanjutnya mengingat penelitian ini memiliki banyak keterbatasan, seperti hanya berfokus pada perusahaan property dan real estate saja, hanya meliputi tahun 2014-2016, dan variabel independen yang diteliti berjumlah empat variabel, maka peneliti selanjutnya dapat menambahkan variabel-variabel yang lain seperti tingkat pertumbuhan penjualan, tingkat suku bunga, current ratio, dan lain sebagainya. Selain itu peneliti selanjutnya dapat meneliti semua sektor perusahaan yang terdaftar di Bursa Efek Indonesia bila perlu meneliti perusahaan dari luar Bursa Efek Indonesia seperti memakai perusahaan dari Singapura, melibatkan jumlah tahun yang lebih lama, meneliti variabel lain yang tidak diteliti dalam penelitian ini, membandingkan antara perusahaan property dan real estate dengan perusahaan non manufaktur, atau menggunakan metode analisa lainnya dan juga menggunakan metode pengolahan data seperti e views, PLS, atau SEM.

\section{DAFTAR RUJUKAN}

Brigham, E, F. \& Houston, F,F. (2010). Essentials of Financial Management: Dasar-dasar Manajemen Keuangan. Penerjemah Ali Akbar Yulianto, Edisi Kesebelas, Edisi Indonesia, Buku 1, Jakarta; Salemba Empat

Brigham, Eugene and Joel F. Houston. (2005). Fundamental of Financial Management. Jakarta : Erlangga.

Febrianti, Meiriska, (20120. "Faktor-faktor yang mempengaruhi nilai perusahaan pada industri pertambangan di Bursa Efek Indonesia". Jurnal Bisnis dan Akuntansi.

Harmono. (2009). Manajemen Keuangan Berbasis Balanced Scorecard (Pendekatan Teori, Kasus, dan Riset Bisnis). Jakarta: Bumi Aksara.

Mahpudin, Endang and Suparno, (2016). "Faktor-faktor yang mempengaruhi nilai perusahaan (Studi empiris pada perusahaan manufaktur yang terdaftar di Bursa Efek Indonesia)". JRKA.

Martono and D. Agus Harjito. (2000). Kebijakan Dividen [on-line]. Available http://ekonomi.kabo.biz/2011/05/kebijakan-dividen.html

Robinhot, Agustina, dan Sri Widia. (2013). "Analisis faktor-faktor yang mempengaruhi nilai perusahaan pada perusahaan farmasi di Bursa Efek Indonesia". Jurnal Wira Ekonomi Mikroskil.

Sartono, Agus. (2010). Manajemen Keuangan Teori dan Aplikasi. Yogyakarta: BPFE.

Sri Hermuningsih dan Dewi Kusuma Wardani. (2009). "Faktor-faktor yang mempengaruhi nilai perusahaan pada perusahaan yang terdaftar di Bursa Efek Malaysia dan Bursa Efek Indonesia”. Siasat Bisnis, 13 (2), 173-183.

Syafri Harahap, Sofyan, (2008). Analisa Kritis atas Laporan Keuangan, PT. Raja Grafindo Persada, Jakarta.

Weston, J. Fred dan Brigham, Eugene F. (1993). Essentialsof Managerial Finance, The Dryden Press. 